\title{
Pengaruh Kombinasi Ischemic Compression Dan Stretching Pada Myofascial Pain Syndrome Otot Upper Trapezius
}

\author{
${ }^{1}$ Nurul Aktifah, ${ }^{2}$ Rifqi Sabita, ${ }^{3}$ Arum Sekar Sunyiwara \\ Sarjana Fisioterapi, Fakultas Ilmu Kesehatan, Universitas Muhammadiyah Pekajangan Pekalongan \\ Jl. Raya Ambokembang No.8, Kecamatan Kedungwuni, Kabupaten Pekalongan \\ Email : rifqisabita95@gmail.com
}

Tanggal Submisi: 14 Desember 2020; Tanggal Penerimaan: 29 Desember 2020

\begin{abstract}
ABSTRAK
Tujuan Penelitian: Untuk mengetahui pengaruh kombinasi ischemic compression dan stretching pada myofascial pain syndrome otot upper trapezius.

Metode Penelitian: Penelitian ini menggunakan pendekatan quasi experiment dan metode two group pre test dan post test. Sampel penelitian ini sebanyak 30 orang yang dibagi menjadi dua kelompok yaitu kelompok 1 (ischemic compression dan stretching) dan kelompok 2 (stretching). Penelitian dilakukan selama 4 minggu dengan dosis 2 kali dalam seminggu. Pengukuran nyeri menggunakan VAS. Teknik analisa data menggunakan uji wilcoxon dan uji mann whitney.

Hasil Penelitian: Berdasarkan hasil statistik untuk uji beda diperoleh p-value 0,000 artinya ada pengaruh dari ischemic compression dan strecthing pada myofascial pain syndrome otot upper trapezius. Sedangkan pada uji beda pengaruh di peroleh p-value 0,01, sehingga dapat disimpulkan bahwa ada beda pengaruh antara pemberian ischemic compression dan stretching pada myofascial pain syndrome otot upper trapezius. Kesimpulan: Pemberian ischemic compression dan stretching terbukti dapat menurunkan nyeri sindroma miofasial upper trapezius. Ischemic compression yang diikuti dengan stretching lebih efektif dalam menurunankan nyeri sindroma miofasial upper trapezius dibandingkan pemberian stretching saja.
\end{abstract}

Kata kunci: Ischemic Compression, Stretching, Myofascial Pain Syndrome Upper Trapezius, Visual Analog Scale (VAS).

\begin{abstract}
Purpose: To determine the combination of ischemic compression and stretching in myofascial pain syndrome upper trapezius muscle.

Methodology: This research uses quasi experimental approaches and methods of two group pre test and post test. Samples of this study were 30 people who were divided into two groups : group 1 (ischemic compression and stretching) and group 2 (stretching). The study was conducted for 4 weeks at a dose of 2 times a week. The pain was measured using the VAS. Data analysis using Wilcoxon test and Mann Whitney test.

Results: Based on the statistical results obtained for different test p-value of 0.000, means that there is the influence of ischemic compression and stretching in myofascial pain syndrome upper trapezius muscle on the respondent. While the influence of different test using the Mann-Whitney test was obtained $p=0.01$, so it can be seen that there is a difference between giving effect Ischemic Compression and Stretching shown to lower the upper trapezius myofascial pain syndrome on the respondent.

Conclusion: Giving Ischemic Compression and Stretching shown to lower the upper Trapezius myofascial pain syndrome. Ischemic Compression followed by auto stretching more effective in decline upper Trapezius myofascial pain syndrome rather than the use of auto stretching alone.
\end{abstract}

Keywords: Ischemic Compression, Stretching, Myofascial Pain Syndrome Upper Trapezius, Visual Analog Scale (VAS). 


\section{PENDAHULUAN}

Nyeri leher merupakan masalah yang umum di jumpai pada masyarakat Indonesia khususnya pada pekerja yang posisi leher statis. Angka kejadian nyeri leher di Indonesia dalam 1 bulan sebesar 10\%, dalam 1 tahun mencapai $40 \%$. Prevalensi nyeri leher pada pekerja mencapai kisaran 6-67\% dan lebih banyak dialami oleh wanita (Falah, 2018), dan 49\% diantaranya dialami oleh pekerja garmen (Suwantini, Wibawa, Griadhi, 2015). Posisi leher yang statis dalam jangka waktu yang lama dan beban kerja otot leher yang berlebihan dapat menyebabkan kontraksi otot leher yang berlebihan sehingga dapat menyebabkan nyeri, spasme pada otot leher yang disebut myofascial pain syndrome (Indriyani, 2015).

Myofascial pain syndrome adalah suatu kondisi nyeri pada otot yang bersifat kronik yang ditandai dengan adanya trigger point. Trigger point adalah titik nyeri yang hipersensitif yang terletak di otot yang menegang atau mengalami pengerasan (taut band). Myofascial pain syndrome disebabkan karena beban kerja otot yang berlebihan, bisa juga disebabkan karena trauma otot. Otot yang bekerja secara berlebihan akan menyebabkan kontraksi terus menerus yang akan menyebabkan otot menjadi tegang sehingga timbul spasme, kekakuan, adhesion serta penurunan sirkulasi darah yang merupakan pemicu timbulnya trigger point di otot yang menegang (Atmadja, 2016).

Salah satu pekerjaan yang beresiko mengalami myofascial pain syndrome adalah pekerja garmen khususnya operator mesin jahit. Penjahit bekerja dengan posisi duduk tegak dan kepala agak menunduk dalam jangka waktu 7-8 jam per hari. Posisi tersebut apabila dilakukan secara berulang-ulang dalam jangka waktu yang lama maka akan menimbulkan berbagai masalah seperti pegal pada punggung bawah karena posisi duduk yang tidak baik, tidak sedikit juga pekerja operator mesin jahit yang mengeluhkan pegal, kaku dan nyeri pada leher karena posisi kepala yang menunduk dalam jangka waktu lama (Kinteki, 2018).

Menurut Dommerholt (2006) pada saat menjahit, aktivitas otot leher lebih dominan menggunakan static lowlevel contraction. Aktivitas tersebut sangat beresiko terhadap terjadinya kelelahan pada kelompok otot ekstensor leher yang mengarah pada otot upper trapezius. Kontraksi otot upper trapezius yang berkepanjangan akan mengakibatkan terjadinya spasme, collagen contracture, adhesion, abnormal crosslink actin myosin, serta terhambatnya aliran darah pada area tersebut. Kondisi tersebut menjadi pemicu timbulnya titik picu nyeri miofasial pada taut band sehingga mengakibatkan terjadinya nyeri sindroma miofasial upper trapezius.

Berbagai modalitas fisioterapi dapat digunakan sebagai intervensi dalam menangani nyeri sindroma miofasial otot upper trapezius antara lain spray and stretch, ultrasound (US), dry needling, ischemic compression, latihan penguluran, dan lain-lain (Hong, 2006). Namun peneliti memilih menggunakan metode Ischemic Compression dan Stretching. Menurut Nambi et al., (2013) Ischemic Compression merupakan suatu teknik yang diaplikasikan dengan memberikan tekanan pada titik nyeri, dilakukan secara perlahan kemudian meningkat hingga batas toleransi nyeri pasien sehingga efektif dan aman dalam mengurangi nyeri pada sindroma miofasial. Sedangkan menurut Chaitow (1996) dikutip dalam Melinda (2015), stretching otot, baik yang dilakukan secara aktif atau metode pasif berguna dalam menangani pemendekan otot dan titik picu nyeri sindroma miofasial karena hal tersebut dapat mengurangi kontraksi dari taut band dan meningkatkan aliran darah didalam jaringan

Manfaat dari ischemic compression dan stretching terhadap penurunan nyeri sindroma miofasial telah dibuktikan melalui beberapa 
penelitian, salah satunya yang dilakukan oleh Hanten et al., (2000) yang membandingkan intervensi A yaitu ischemic compression diikuti penguluran pasif dengan intervensi B yaitu latihan aktif. Hasil yang diperoleh mengarah pada intervensi A lebih baik terhadap penurunan nyeri yang diukur dengan VAS, setelah lima hari berturut-turut dilakukan terapi.

Berdasarkan latar belakang yang telah diuraikan diatas, membuat peneliti ingin mengetahui pengaruh kombinasi ischemic compression dan stretching terhadap myofascial pain syndrome otot upper trapezius pada pekerja garmen DNY Jeans Wonopringgo Pekalongan.

\section{METODE PENELITIAN}

Jenis penelitian ini adalah eksperimental dengan pendekatan quasi eksperiment dan metode two group pretest and posttest. Serta teknik pengambilan sampel menggunakan purposive sampling. Penelitian dilakukan pada bulan Agustus sampai September 2019 selama 4 minggu dengan dosis 2 kali dalam seminggu, di Garmen DNY Jeans, Desa Rowokembu, Kecamatan Wonopringgo. Jumlah sampel dalam penelitian ini sebanyak 30 orang, yang terbagi atas kelompok 1 dan kelompok 2 dengan teknik randomisasi. Kelompok 1 sebanyak 15 sampel diberikan perlakuan Ischemic Compression dan Stretching. Dan kelompok 2 sebanyak 15 sampel diberikan perlakuan Stretching.

Alat ukur nyeri pada penelitian ini menggunakan Visual Analog Scale (VAS). Responden diukur tingkat nyerinya sebelum dan sesudah diberikan intervensi. Ischemic compression adalah teknik trigger point release yang dilakukan dengan cara mengaplikasikan tekanan yang perlahan meningkat kemudian menurun intensitasnya. Posisi awal subjek adalah duduk dengan otot upper trapezius yang akan diterapi dalam keadaan terulur. Kemudian dilakukan penekanan dengan cara mengangkat otot yang memiliki titik nyeri seperti gerakan mencubit (pincer grasp). Tekanan ditingkatkan secara bertahap dan ditahan selama 60 detik dengan intensitas nyeri dinilai dengan VAS.

Teknik stretching dilakukan dengan posisi subjek duduk nyaman dengan satu tangan memegang kepala, dan tangan yang satunya berada di belakang punggung kemudian lakukan tarikan kepala ke arah lateral fleksi ipsi lateral sampai terasa nyeri kemudian turukan sedikit, pasien diminta utuk menahan posisi tersebut selama 6 detik kemudian lakukan stretch selama 10 detik

\section{HASIL}

Pada bab ini peneliti membahas tentang hasil penelitian yang dilakukan pada responden garmen khususnya pada operator mesin jahit yang bekerja dengan posisi leher statis dalam jangka waktu lama. Karakteristik responden pada saat penelitian ratarata umur responden adalah 26,15 dengan standar deviasi 6,699. Semua responden pada penelitian ini berjenis kelamin perempuan sesuai dengan kriteria inklusi peneliti.

\begin{tabular}{cccc}
\hline Variabel & T & Df & P value \\
\hline $\begin{array}{c}\text { MPS sebelum dan } \\
\text { MPS sesudah }\end{array}$ & 36,080 & 29 & 0,000 \\
\end{tabular}

Tabel 1. Pengaruh Kombinasi Ischemic Compresion dan Stretching pada Myofascial Pain Syndrome Otot Upper Trapezius

Berdasarkan hasil dari tabel 1, analisa statistik menggunakan uji Wilcoxon didapatkan hasil $\rho$ value sebesar 0,000 dimana nilai $\rho$ value $<0,05$ maka Ho ditolak yang artinya ada pengaruh yang signifikan terhadap penurunan nyeri pada kombinasi Ischemic Compresion dan Stretching pada Myofascial Pain Syndrome Otot Upper Trapezius pada pekerja garmen Kecamatan Wonopringgo.

\section{PEMBAHASAN}

\section{Usia}

Hasil penelitian menunjukan bahwa angka kejadian sindroma miofasial pada penjahit paling banyak terjadi pada usia 25-40 tahun sebesar 60\% 
(kelompok 1) dan 90\% (kelompok 2). Hal tersebut disebabkan pada rentang usia 25-40 mulai terjadi perubahan pada sistem muskuloskeletal, dimana masa otot mulai berkurang terutama yang ditandai dengan hilangnya serabut otot tipe 1 dan 2 . Perubahan ini menyebabkan laju metabolik basal dan laju komsumsi oksigen maksimal berkurang sebesar 4,5\%. Otot menjadi mudah lelah dan kecepatan laju kontraksi melambat. Pada kelompok usia pertengahan, keluhan nyeri leher disebabkan oleh nyeri sindroma miofasial dan nyeri post trauma.

Berdasarkan penelitian yang telah dilakukan oleh Giamberardino et al., (2011) menyatakan bahwa prevalensi usia terjadinya sindroma nyeri miofasial adalah pada usia pertengahan (30-60 tahun). Selain itu, saat usia 30 tahun mulai terjadi degenerasi pada wanita. Hal ini ditandai dengan adanya degenerasi pada tulang dan sendi disertai dengan hilangnya fleksibilitas miofasial secara bertahap sehingga memicu timbulnya sindroma nyeri miofasial (Yap, 2007).

\section{Pemberian Ischemic Compression dan Stretching}

Pemberian ischemic compression dan stretching berpengaruh secara signifikan terhadap penurunan nyeri sindroma miofasial upper trapezius dalam penelitian ini. Berdasarkan hasil uji beda wilcoxon terhadap kelompok 1 yang diberikan ischemic compression dan stretching diketahui nilai $\mathrm{P}$ 0,000 atau $\mathrm{p}<0,05$ yang artinya ada pengaruh ischemic compression dan stretching terhadap penurunan nyeri sindroma miofasial upper trapezius. Hal tersebut sesuai dengan penelitian yang telah dilakukan oleh Iqbal (2010) yang menyatakan bahwa mekanisme Ischemic compression yang dalam aplikasinya menggunakan prinsip penekanan (kompresi) pada titik picu nyeri miofasial upper trapezius dengan menginaktifkan titik picu nyeri miofasial tersebut. Sehingga meningkatkan suplai darah lokal yang mengakibatkan eksudat inflamasi dan metabolit nyeri dapat didorong keluar menuju sistem peredaran darah. Kemudian zat sisa metabolisme penyebab nyeri tersebut akan terbawa bersama dengan aliran darah sehingga nyeri berkurang.

Modalitas ini juga berperan dalam menghancurkan scar tissue sehingga serabut otot dapat bergerak dengan baik. Otot akan dinutrisi oleh aliran darah ekstra dan ujung-ujung saraf akan didesentisasi sehingga tonus otot akan menurun. Lebih lanjut, mengenai aplikasi ischemic compression juga dapat menginhibisi nyeri miofasial melalui mekanisme pelepasan $\beta$ endorfin karena rangsangan noksius yang terjadi akan merangsang serabut saraf tipe A delta. Serabut saraf tipe A delta akan memodulasi nyeri dengan aktivasi pelepasan senyawa endogen opioid berupa $\beta$ endorfin oleh hipotalamus.

Berdasarkan hasil uji beda wilcoxon pada kelompok 2 diperoleh nilai $\mathrm{P} 0,000$ atau $<0,05$ yang berarti ada pengaruh stretching terhadap penurunan nyeri sindroma miofasial. Hal ini dibuktikan bahwa stretching dapat mengurangi nyeri sindroma miofasial dengan cara menstimulasi golgi tendon organ (GTO), yang kemudian jumlah sakomer meningkat, mengakibatkan pelepasan zat adhesi, sehingga terjadi relaksasi otot, meningkatnya elastisitas otot dan fleksibilitas otot, nyeri pun berkurang (Herbert, 2002).

Pemberian stretching tersebut menunjukkan adanya penurunan nyeri sindroma miofasial yang disebabkan kemampuan untuk memanjangkan atau mengulur struktur jaringan lunak seperti otot, fasia, tendon dan ligamen yang memendek akibat patologis sehingga dapat mengurangi nyeri yang disebabkan karena spasme, pemendekan otot atau akibat fibrosis. Hal ini sesuai dengan pendapat yang dikemukakan oleh Gerwin (2005), bahwa Stretching merupakan salah satu usaha untuk mengembalikan panjang dan fleksibilitas otot maupun fasianya dengan menempatkan bagian tubuh agar terjadi penguluran pada jaringan otot. Dengan stretching otot akan dilatih untuk memanjang yang kemudian mempengaruhi sarkomer dan fasia dalam miofibril otot. Pemanjangan sarkomer dan fasia ini akan mengurangi derajat overlapping. 
Dari aspek neurologis, saat otot diulur maka golgi tendon organ juga akan terulur. Hal ini menyebabkan impuls dari saraf gamma menurun dan relaksasi pada otot yang diulur pun akan terjadi (Berry, 2006). Otot yang rileks memiliki sirkulasi darah yang lancar sehingga terjadi perbaikan proses metabolisme otot dan metabolisme aerobik pun dapat terjadi (Kostopoulus, 2008). Penguluran yang dilakukan tanpa menimbulkan rasa sakit juga akan memberi stimulus pada serabut saraf tipe A beta. Serabut saraf tipe ini akan memodulasi nyeri pada tingkat spinal tepatnya pada lamina II di posterior horn cell (PHC) dan menghambat transmisi nyeri oleh serabut saraf tipe C.

\section{KESIMPULAN DAN SARAN}

Kesimpulan pada penelitian ini adalah ada pengaruh kombinasi ischemic compression dan stretching pada myofascial pain syndrome otot upper trapezius. Terdapat perbedaan pengaruh antara kelompok I (ischemic compression dan stretching) dan kelompok 2 (stretching). Pada kelompok I menunjukan penurunan nyeri yang lebih baik dibandingkan kelompok 2 yang hanya diberikan stretching.

Pada penelitian tentang myofascial pain syndrome selanjutnya, peneliti menyarankan agar dapat menggunakan alat ukur nyeri yang bersifat obyektif.

\section{UCAPAN TERIMAKASIH}

Peneliti mengucapkan terimakasih pada Universitas Muhammadiyah Pekajangan Pekalongan, pemilik Garmen DNY Jeans Wonopringgo dan seluruh responden yang telah mendukung penelitian.

\section{DAFTAR PUSTAKA}

Dommerholt, J.D., Bron, C., Franssen, J. Myofascial Trigger Points: An EvidenceInformed Review. The Journal of Manual and Manipulative Therapy. 2006; 14 (4) : 203-221

Falah, M.A. Pengaruh Penambahan Stretching Exercise pada Kompres Panas terhadap
Penurunan Nyeri pada Neck Pain Syndrome. Skripsi, Universitas Muhammadiyah Surakarta. 2018.

Giamberardino., Affaitati., Fabrizio., Costantini. Myofascial pain syndrome and their evaluation. Elseiver Journal. 2011; 2 : 185-98

Indriyani, N.K. Pengaruh Myofascial Release terhadap Pengurangan Nyeri pada Myofascial Trigger Points Syndrome Otot Upper Trapezius pada Pembatik di Desa Jarum Bayat. Skripsi, Universitas Muhammadiyah Surakarta. 2015.

Iqbal, A., Khan, S.A., Miraj, M. Efficacy of Ischaemic Compression Technique in Combination with Strain Counterstrain Technique in Managing Upper Trapezius Myofascial Trigger Point Pain. Indian Journal of Physiotherapy and Occupational Therapy. 2010; 4 (2) : 10-15

Kinteki, L.Z. Pengaruh Kinesio Taping dan Muscle Energy Technique terhadap Penurunan Nyeri Myofascial Pain Syndrome Otot Upper Trapezius pada Penjahit di Adevia Konveksi. Skripsi, Universitas Muhammadiyah Surakarta. 2018.

Melinda, G. Pengaruh Pemberian Ischemic Compression dan Penguluran Pasif Terhadap Penurunan Nyeri Sindroma Nyeri Miofasial Upper Trapezius pada Pekerja Konveksi. Skripsi, Surakarta: Politeknik Kesehatan Surakarta. 2015.

Nambi, G.S., Sharma, R., Inbasekaran, D., Vaghesiya, A., Bhatt, U. Difference in Effect Between Ischemic Cmpression and Mscle Energy Technique on Upper Trapezius Myofascial Trigger Points: Comparative Study; International Journal of Health\&Allied Sciences. 2013; 2 (1) : 17- 22

Suwantini, P.W.N, Wibawa, A \& Griadhi, A.P.I. Auto Stretching Lebih Menurunkan Intensitas Nyeri Otot Upper Trapezius Daripada Neck Cailliet Exercise pada Penjahit Payung Bali di Desa Mengwi Kecamatan Mengwi Kabupaten 
Aktifah N., Sabita R \& Sunyowara A.S Fisiomu.2021 Voll 2(1): 47-53 DOI : $10.23917 /$ fisiomu.v2i1.12911

Badung. Jurnal Skripsi Fisioterapi. Universitas Udayana. 2015.

Wijaya, I.P.A., Yantini, K.E., Susila, M.D.P. Faktor-faktor yang Yempengaruhi Intensitas Nyeri Pasien Pasca Operasi Fraktur
Ekstremitas Bawah di BRSU Tabanan. 2018; 2 (1) : 6-10.

Atmadja, S.A. Sindrome Nyeri Myofascial. Continuing Medical Education. 2016; 43 (3): 176-177. 